per one of pure water, the under one of phosphuret of sulphur, and between those two layers, there is a very thin stratum of white poyder, which, when the matrass is exposed to the sun's rays, exhibits all the colours of the prism; and which, consequently, appears to be formed of a multitude of little crystals.

Encouraged by this experiment, M. Gaunal endeavoured, by the following process, to obtain larger crystals, and succeeded. He introduced into a matrass, placed where it would be quite undisturbed, first eight ounces of water, and then eight ounces of carburet of sulphur, and eight ounces of phosphorus. As in the preceding experiment, the phosphorus dissolved; and the three liquids arranged themselves in the order of their specific gravity. After four-and : twenty hours, there was formed between the layer of water and the layer of carburet of sulphur, an extremely thin pellicle of white powder, having here and there several air-bubbles, and various centres of crystallization, formed, some by spars of very thin sheets, and others by stars. In the course of a few days, this pellicle gradu. ally grew thicker. At the same time, the separation of the two inferior liquids became less complete; and in three months they appeared to form but one and the same substance. Another month having elapsed without any new result, the question was, how to find means of separating the crystallized substance from the phosphuret of sulphur, to which the inflammability of the mixture presented great obstacles. After several attempts, more or less unsuccessful, M. Gannal determined to filter the whole through a chamois skin, which he afterwards placed under a glass bell, taking care, from time to time, to renew the air. At the end of a month, this skin becoming capable of being handled without inconvenience, it was doubled up, washed, and dried. For the first time, M. Gannal was then enabled to examine the crystallized substance which remained on its surface. Exposed to the sun's rays, this substance presented numerous crystals, reflecting all the colours of the rainbow. Twenty of them were large enough to be taken up with the point of a penknife; and three others were of the size of a grain of millet. These last, having been submitted to the inspection of an experienced jeweller in Paris, were pronounced by him to be real diamonds! A. M. Delatour states that he has, also, produced the diamond by a different process, of which a brief notice shall appear in our next.

[Lit Gazette.

\title{
Great Ship Canal of the Notherlands.
}

Tya object of the Great Canal, is, to afford a passage for large vessels from Amsterdam to the sea. This city has forty feet of water in the road in front of its port, but the Pampas, or bar in the Zayder Zee, seven miles below, has only a depth of ten feet, and hence all ships of any considerable burden, have to unload part of their cargves with lighters, before they enter the port. $\Lambda$ s the sea 
in question is full of shallows throughout, all ordinary means of improving the access to the port, were necessarily ineffectual; and the resulution was, therefore, at length adopted, of cutting a canal from the town to the Helder, the northemmost point of the province of Holland. The distance between these extreme points is 41 Eng $g$ ish miles, but the length of the canal is about 503. "The breadth at the surface of the water, is 124 . English feet (120 Rhinland feet $;$ ) the breadth at bottom 36; the depth, 20 feet 9 inches. Like the Dutch canals, generally, its level is that of the high tides of the sea, from which it receives its supply of water. The only locks it requires, of course, are two tide locks at the extremities; but there are, besides, two sluices with flood-gates in the intermediate space. It has only cighteen bridges (draw-bridges) in its whole length. The locks. and sluices ate double, that is to say, there are two in the breach of the canal; and we learn from Mr. Bald, that their construction and workmanship are excellent. They are built of brick for economy, but bands of lime-stone are interposed at intervals, and these project about an inch beyond the brick, to protect it from abrasion by the sides of the vessels. There is a broad towing-path on each side, and the canal is wide enough to adnit of one frigate passing another. From the river Ye at Amsterdam, it proceds north to Purmerend, thence west to $\Lambda \mathrm{lkmar}$ Lake, thence north by Alkman to a point within two miles of the coast, near Petten, and it continues to run nearly parallel to the coast from this point to the I I Ider, where it joins the sea, at the fine harbour of Niewediep, formed within the last thirty years. At the latter place, there is a powe ful steam engine for supplying the canal with water during neap tides, and other purposes. The time spent in tracking vessels from the Holder to Amsterdam, is eighteen hours. The Helder point is the only spot on the shores of flolland that has deep water; and it cowes this advantage to the Island of 'Iexel, opposite, which, by contracting the communication between the Geman Ocean and the $Z u Y$ der Zee, to a brealth of a mile, produces a current which scours and decpens the channel. Immediately opposite the.Helder, there is 100 feet of water at high tides, and at the shallowest part of the bac to the westward, there are twenty-seven feet. In the same way, the artificial mound which runs into the lake or river Ye, opposite $A$ msterdam, by contracting the water-way to about 1000 feet, keeps a depth of forty feet in the purt (at high water, while above and below there is only ten or twolve. The canal was begun in 1819 , and finished in 1895 . The cost was estimated at ten of twelve millions of florins, or about one million sterling. If we compate the in agirtude of this canal by the cubic contents of its bed, it is the greatest, we believe, in the world, unless some of the Chinese camls be exceptions. The volume of water which it contains when filled, or the prism de remplissage, is twice as great as that of the $\mathrm{New} \mathbf{Y}$ ork Canal, ot the Canal of Languedoc, and two and alf times as great as that of the Caledoniun Canal, if we include only those parts of the latter which have been cut with human labour.

[Lomd. Aet Monhly Mres. 
Franklin Institute.

A MEETING of the board of managers was held at the hall, January 20,1829 .

James Ronaldson, president, in the chair.

The actuary read so much of the minutes of the annual meeting of the Institute, held the 15 th inst. as related to the election of this board.

Whereupon, the board went into an election for chairman and curators for the ensuing year. Messrs, Samuel J. Robbins and Isaac B. Garrigues, were appointed tellers, who reported the following gentlemen duly elected, viz.

HeNRY Hors, Chairman,

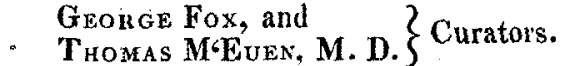

On motion, it was Resolved, that the stated meetings of this board be held on the second Thursday evening in every month.

The candidates proposed at the last meeting of the former board, were duly elected members of the Institute.

A stated meeting of the board of managers was beld at the hall on Thursday, February 12, 1829.

Mr. Henry Horn, chairman.

The minutes of the last meeting were read and approved.

The chairman appointed the following standing committees, which were approved by the board, viz.

On Instruction.

\begin{tabular}{|c|c|}
\hline $\begin{array}{l}\text { George Fox, } \\
\text { J. B. Garrigues, } \\
\text { Henry Horn, } \\
\text { 'Thomas M'Euen, M. D. } \\
\text { Wm. Yardley, jr. }\end{array}$ & $\begin{array}{l}\text { Isaac Collins, } \\
\text { Charles Wheeler, } \\
\text { C. D. Meigs, M.D. } \\
\text { Charles Roberts, } \\
\text { R. R. Lewis. }\end{array}$ \\
\hline \multicolumn{2}{|c|}{ On the Library. } \\
\hline $\begin{array}{l}\text { Isaac Hays, M. D. } \\
\text { Charles H. White, } \\
\text { George Fox, }\end{array}$ & $\begin{array}{l}\text { Thomas Loud, } \\
\text { Frederick Fraley. }\end{array}$ \\
\hline \multicolumn{2}{|c|}{ On the Cabinet of Models. } \\
\hline $\begin{array}{l}\text { Rufus Tyler, } \\
\text { John Struthers, } \\
\text { Joln O'Neill, } \\
\qquad \text { On the Cabin }\end{array}$ & $\begin{array}{l}\text { Joseph H. Schreiner, } \\
\text { Thomas Scattergood. }\end{array}$ \\
\hline $\begin{array}{l}\text { Abraham Miller, } \\
\text { Isaiah Lukens, } \\
\text { Isaac Hays, M. D. } \\
\text { On Premiums }\end{array}$ & $\begin{array}{l}\text { Thomas M(Euen, M. } \\
\text { James Rowland, jr. }\end{array}$ \\
\hline $\begin{array}{l}\text { James Ronaldson, } \\
\text { Adam Ramage, } \\
\text { Isaiah Lukens, } \\
\text { Mordecai D. Lewis, }\end{array}$ & $\begin{array}{l}\text { Christian Gobrecht, } \\
\text { Mathias W. Baldwio, } \\
\text { Samuel J. Robbins, } \\
\text { Algernon S. Roberts. }\end{array}$ \\
\hline
\end{tabular}


On Publicutions.

$\begin{array}{ll}\text { Samuel V. MRrick, } & \text { Isaiah Lukens, } \\ \text { Isaac Hays, M. I). } & \text { Mathias W. Baldwin. } \\ \text { Rufus Tyler, } & \end{array}$

On Inventions.

Jumes Ronaldson, Mathias W. Baldwin,

Andrew Young,

Christian Gobrecht, Samuel V. Merrick, Isaiah Lukens, Benjamin Reeves.

\author{
Managers of the Sinking Fund. \\ Samuel V. Merrick, \\ Ashbel G. Ralston, \\ Samuel J. Robbins. \\ Auditors. \\ Abraham Miller, \\ Isaac B. Garrigues.
}

The special committec appointed by the late boat, at the request of $\mathrm{Mr}$. Isaac $\mathrm{M}$ 'Cauley, to visit his floor cloth manutactory, presented a report, which was read, and on motion, the actuary was firected to fumish $\mathrm{Mr}$. M'Cauley with a copy.

'The corresponding secretary presented the following communications, viz. a work, entitled, "Du Développement, à donner àquelques parties principales et essentielles de notre Industrie Interieure," from the author, M. de Moleon, Chief Engineer of the king's cabinet, and of the Royal Domains of France. And, also, a letter from the saine, requesting to be elected a correspondent. A letter from $M$. Chersant, Vice Consul of France, enclosing the above, and offering to transmit any communications for the Institute. - A letter from the Franklin Institute of Rochester, New York, acknowledging the receipt of the Journal of the Franklin Institute, for the past year, and expressing a desire to continue the correspondence.

Whereupon, it was Resolved, that the corresponding secretary be instructed to forward the Journal of the Institute to that Institution, as published, and to continue the correspondence.

On motion, it was Resolved; that a conmittee be appointed to report to this board the design and expense of a diploma of membership, to be issued to the members of the Institution. Isaac Mays, M. D., and Messrs. Samuel V. Merrick and Thomas Lond weve appointed said committec.

Resolved, that the above committee be instructed, also, to report the design of a certificate, to accompany the medals awarked at the exhibitions of the Institution.

Resolved, that a committee be appointed to report a plan for the monthly meetings of the Institution. Isaac Ilays, M. D., and Messrs. Samuel $\checkmark$. Merrick and Rufus Tyler were appointed said committee.

Resolved, that a committee be appointed to have cases for the cabinets of minerals and models put in the meeting room. Isate 
Hays, M. D., Thomas $M^{\bullet}$ Euen, M. D., and Mr. Isaiah Lukens, were appointed said committee.

Resolved, that the committee on premiums and exhibitions be instructed to prepare a list of premiums to be awarded at the next exhibition to be held by the Institute.

The election of members of the Institute, proposed at the lost meeting, was called for, when $M$. de Moleon, of france, was duly elected a correspondent, and Dr. Thomas P. Jones, of Washington city, an honorary member, and the remaining candidates were elected members of the Institution. Extract from the minutes.

William Hamiton, Actwary.

\section{Prevention of Forgery.}

[From Silliman's Journal.]

Messrs. James Atwater and N. \& S. S. Jocelyn, of this city, (New Haven, have completed a plan to prevent forgeries and alterations of bank checks, drafts, bills of exchange, post notes, notes of hand, and other similar instruments.

The labour of carrying into effect such a design, may be, in some measure, understood, when it is considered, that to the accomplishment of a plan which shall obviate all the difficulties of the present mode of doing business, particularly by means of checks, the several following points should be compassed, viz.

Banks should be protected arainst losses arising from the depredations of swindlers, effected both by original forgeries and by alterations of grenuine checks; and the characters of honest dealers, and tellers of banks, should be preserved from the unjust suspicions which may now, sometimes, arise from the impossibility of tracing a forgery to its origin. All these exposures exist in the present mode of transacting the business of banks, and the calamitous consequences too frequently arrest the public attention.

That these various objects can be embraced in one plan, within the ordinary limits of instruments of the kinds referred to, and yet admit of that simplicity and facility wlich the rapid transaction of business requires, is an idea, which, if it ever occurred to any person, was, probably, regarded only as something to be desired, but scarcely to be hoped for; and, consequenily, the old and exposed method has continued in use, with all its temptations to the vicious and the unfortunate. It is believed that no attempts have been made hitherto, to accomplish more than one of these objects, and that with but doubtful success.

The inventors of the plan now spoken of (which they have secured by patent) claim to themselves the merit of conceiving and executing the whole combination of desiderata, and of removing all the obstacles which necessarily present themselves, in an attempt to establish a consistency in the union of so many important points. In the labour and experiments consequent on this undertaking, they have Vol III,-No. 2,-Verauan Y, 1829. 